\title{
MENGENAL SISTEM INFORMASI MANAJEMEN
}

Fedila Jelvita

fedilajelvita@gmail.com

\begin{abstract}
Abstrak
Artikel ini bertujuan untuk mengetahui dan mengenal lebih dalam sistem informasi manajemen. Dalam artikel ini dijelaskan maksud dari sistem informasi manajemen, manfaat, tujuan serta implementasi sistem infirmasi manajemen. Sistem informasi manajemen dapat mempermudah dalam mengelola dan mendapatkan data atau informasi. Sistem informasi manajemen adalah suatu sistem yang terdiri beberapa elemen/komponen yang menyediakan informasi untuk mendukung kegiatan manajemen, pengambilan keputusan dalam suatu organisasi.
\end{abstract}

Kata Kunci: sistem informasi manajemen

\section{A. PENDAHULUAN}

Perubahan yang sangat cepat dalam bidang teknologi dan informasi telah mengubah cara organisasi dikelola pada masa yang akan. Sebagai akibatnya, sudah seharusnya manejer bertindak sebagai agen perubahan.

Informasi dapat diibaratkan sebagai darah yang mengalir di dalam tubuh manusia, seperti halnya di dalam organisasi informasi sangat penting untuk mendukung kelangsungan perkembangannya, sehingan dapat dikatakan bahwa informasi sangat dibutuhkan bagi sebuah perusahaan atau organisasi.

Sistem informasi manajemen merupakan sebuah bidang yang mulai berkembang sejak tahun 1960-an. sistem informasi manajemen adalah suatu sistem yang terdiri beberapa elemen/komponen yang menyediakan informasi untuk mendukung kegiatan manajemen, pengambilan keputusan dalam suatu organisasi.

\section{B. PEMBAHASAN}

\section{Pengertian SIM}

Kata sistem berasal dari bahasa Yunani, yaitu systema, yang artinya himpunan bagian atau komponen yang saling berhubungan secara teratur dan 
merupakan suatu keseluruhan. Selain itu, bisa diartikan sekelompok elemen atu unsur yang independen, namun saling terkait sebagai satu kesatuan.

Menurut Notohadiprawiro (Prihartanto, 2011) Informasi itu sendiri secara umum menyiratkan suatu pengumpulan data yang terorganisasi beserta tatacara penggunaannya yang mencakup lebih jauh dari pada sekedar penyajian data. Menurut Ludwig (Rusdiana \& Irfan, 2014) sistem adalah seperangkat unsur yang saling berhubungan dan saling memengaruhi dalam satu lingkungan lingkungan tertentu. Menurut Gordan B. Davis (Rusdiana \& Irfan, 2014) sistem merupakan bagian bagian yang beroperasi secara bersama-sama untuk mencapai beberapa tujuan.

Dengan demikian dapat disimpulkan bahwa sistem adalah kumpulan dari unsur-unsur atau komponen-komponen yang menjadi satu kesatuan yang saling berkaitan satu sama lain untuk mencapai tujuan.

Informasi atau dalam bahasa Inggrisnya adalah information, berasal dari kata informacion bahasa Prancis. Kata tersebut diambil dari bahasa Latin, yaitu "informationem" yang artinya "konsep, ide, garis besar".

Menurut Wawan dan Munir (Rusdiana \& Irfan, 2014) informasi merupakan hasil dari pengolahan data dalam suatu bentuk yang menggambarkan kejadian nyata dengan lebih berguna dan lebih berarti. Menurut (Rusdiana \& Irfan, 2014) informasi merupakan suatu keberhasilan sesuatu yang dihasilkan dari pengolahan data. Data yang sudah ada dikemas dan diolah sedemikian rupa sehingga menjadi sebuah informasi yang berguna. Menurut George (Rusdiana \& Irfan, 2014) mendefinisikan informasi adalah data yang diolah sehingga dapat dijadikan dasar untuk mengambil keputusan yang tepat.

Dari uraian diatas maka dapat disimpulkan bahwa informasi merupakan hasil dari pengolahan data yang dapat dijadikan sebagai dasar untuk mengambil keputusan yang tepat.

Sistem informasi manajemen merupakan sebuah bidang yang mulai berkembang sejak tahun 1960-an. Menurut O'Brien (Rusdiana \& Irfan, 2014) sistem informasi manajemen adalah sistem terpadu yang menyediakan informasi untuk mendukung kegiatan operasional, manajemen, dan fungsi pengambilan keputusan dari suatu organisasi. Menurut Wikipedia (Rusdiana \& Irfan, 2014) Sistem informasi manajemen merupakan sistem informasi yang mendapatkan hasil keluaran (output) dengan menggunakan masukan (input) dan berbagai 
proses yang diperlukan untuk memenuhi tujuan tertentu dalam kegiatan manajemen. Stoner (Rusdiana \& Irfan, 2014) Sistem informasi manajemen merupakan metode formal yang menyediakan informasi yang akurat dan tepat waktu pada manajemen untuk mempermudah proses pengambilan keputusan dan membuat organisasi dapat melakukan fungsi perencanaan, operasi secara efektif dan pengendalian.

Menurut Sabandi (Agustiandra, Vindi \& Sabandi, 2019) SIM merupakan sebuah sistem yang terdiri dari beberapa elemen/komponen yang saling berkaitan. Elemenelemen/komponen dari sebuah sistem ini tentu saja akan saling terkoordinasi dengan baik agar dapat mencapai tujuan yang ingin dicapai. Secara sederhana, semua sistem informasi memiliki tiga kegiatan utama di dalamnya.

Jadi dapat disimpulkan bahwa sistem informasi manajemen adalah suatu sistem yang terdiri beberapa elemen/komponen yang menyediakan informasi untuk mendukung kegiatan manajemen, pengambilan keputusan dalam suatu organisasi.

\section{Manfaat SIM}

Menurut (Rusdiana \& Irfan, 2014) Sistem informasi manajemen mempunyai keunggulan, yaitu dapat menolong perusahaan untuk meningkatkan efisiensi operasional, memperkenalkan inovasi dalam bisnis, dan membangun sumber-sumber informasi strategis. Adapun manfaat sistem informasi manajemen yaitu sebagai berikut:

a. Meningkatkan aksebilitas data yang disajikan secara tepat dan akurat bagi para pemakai atau pengguna, tanpa harus adanya perentara sistem informasi.

b. Menjamin tersedianya kualitas dan keterampilan dalam menfaatkan sistem informasi secara kritis.

c. Mengembangkan proses perencanaan secara efektif.

d. Mengidentifikasi kebutuhan akan keterampilan pendukung sistem informasi.

e. Menetapkan investasi yang akan diarahkan mengantisipasi dan memahami konsekuensi ekonomi dari sistem informasi dan teknologi baru.

f. Memperbaiki produktivitas dalam aplikasi pengembangan dan pemeliharaan sistem. 
g. Mengelola transaksi, menguragi biaya dan menghasilkan pendapatan sebagai salah satu prosek atau pelayanan.

\section{Tujuan}

Ada beberapa tujuan dari sistem informasi manajemen menurut (Rusdiana \& Irfan, 2014) yaitu sebagai berikut:

a. Menyedikan informasi yang digunakan dalam menghitung harga pokok jasa dan produk.

b. Menyedikan informasi yang digunakan dalam perencanaan.

c. Menyedikan informasi yang digunakan dalam pengendalian.

d. Menyedikan informasi yang digunakan dalam pengevaluasian dan perbaikan berkelanjutan.

e. Menyediakan informasi untuk pengambilan keputusan.

\section{Implementasi SIM dalam Manajemen Sekolah}

Dengan kemajuan teknologi pada saat ini, sistem informasi berbasis komputer dapat diterapkan dalam berbagai hal yang dapat membantu menyelesaikan permasalahan yang dihadapi sekolah.

Contohnya yaitu dalam mengelola aset sekolah sebelumnya dilakukan dengan cara ditulis dalam buku atau secara manual yang masih tersebar dan susunannya tak rapi. Keadaan ini menimbulkan permasalahan dalam mengetahui jumlah total dan detail aset yang dimiliki serta kondisinya. Tetapi dengan perkembangan zaman dan adanya sistem informasi manajemen permasalahan ini dapat diatas dengan mengelola aset sekolah berbasis teknologi web. Sistem yang dapat diterapkan yaitu mempunyai fasilitas untuk mengelompokkan aset, memasukkan aset, jumlah aset dan sebagainya. Dengan demikian dapat mempermudah dalam mendapatkan data dan informasi mengenai aset-aset yang dimiliki sekolah.

\section{Kesimpulan}

Sistem informasi manajemen dapat mempermudah dalam mengelola dan mendapatkan data atau informasi. Sistem informasi manajemen adalah suatu sistem yang terdiri beberapa elemen/komponen yang menyediakan informasi untuk mendukung kegiatan manajemen, pengambilan keputusan dalam suatu organisasi. Dalam manajemen sekolah sistem informasi manajemen sangat membantu sekolah dalam mengelola data, aset, promosi sekolah dan sebagainya. 


\section{REFERENSI}

Agustiandra, Vindi \& Sabandi, A. (2019). Persepsi Guru Terhadap Penerapan Sistem Informasi Manajemen Akademik Sekolah Menengah Kejuruan (SMK) Negeri 3 Padang. Jurnal Bahana Manajemen Pendidikan, 8(1), 1-8. Retrieved from http://ejournal.unp.ac.id/index.php/bahana

Prihartanto, Y. L. (2011). Sistem Informasi Manajemen Agenda Pada Badan Pelayanan Perijinan Terpadu Kabupaten Karanganyar. Journal Speed - Sentra Penelitian Engineering Dan Edukasi, 3(3), 53-58.

Rusdiana \& Irfan, M. (2014). Sistem Informasi Manajemen (Pertama; B. A. Saebani, ed.). Bandung: CV Pustaka Setia. 